\begin{tabular}{lc} 
HARMONI SOSIAL & $\begin{array}{c}\text { Harmoni Sosial: Jurnal Pendidikan IPS } \\
\text { Volume 4, No 2, September 2017 (165-175) } \\
\text { Jurnal Pendidikan IPS } \\
\text { Online: http://journal.uny.ac.id/index.php/hsjpi }\end{array}$ \\
\hline
\end{tabular}

\title{
PENGARUH MODEL PEMBELAJARAN INKUIRI TERHADAP KETERAMPILAN BERPIKIR KRITIS DAN HASIL BELAJAR PESERTA DIDIK DALAM PEMBELAJARAN PPKn
}

\author{
Ani Sulianti * ${ }^{1}$, Mukhamad Murdiono ${ }^{1}$ \\ ${ }^{1}$ Universitas Negeri Yogyakarta \\ ${ }^{1} \mathrm{Jl}$. Colombo No. 1, Depok, Sleman 55281, Yogyakarta, Indonesia \\ * Corresponding Author. Email: anisulianti@gmail.com
}

\begin{abstract}
Abstrak
Penelitian ini bertujuan untuk mengetahui pengaruh model pembelajaran inkuiri terhadap: (1) keterampilan berpikir kritis dan (2) hasil belajar peserta didik dalam pembelajaran Pendidikan Pancasila dan Kewarganegaraan di SMA Negeri 3 Lumajang. Penelitian ini merupakan penelitian quasi experiment. Instrumen yang digunakan adalah observasi dan tes. Data dianalisis dengan menggunakan uji-t. Hasil penelitian, adalah sebagai berikut: (1) Terdapat pengaruh yang signifikan model pembelajaran inkuiri terhadap keterampilan berpikir kritis peserta didik dalam pembelajaran Pendidikan Pancasila dan Kewarganegaraan di SMA Negeri 3 Lumajang pada Kompetensi Dasar menganalisis indikator ancaman terhadap negara dalam membangun integrasi nasional dengan Bhineka Tunggal Ika. (2) Terdapat pengaruh yang signifikan model pembelajaran inkuiri terhadap hasil belajar peserta didik dalam pembelajaran Pendidikan Pancasila dan Kewarganegaraan di SMA Negeri 3 Lumajang pada Kompetensi Dasar menganalisis indikator ancaman terhadap negara dalam membangun integrasi nasional dengan Bhineka Tunggal Ika.
\end{abstract}

Kata kunci: inkuiri, keterampilan berpikir kritis, hasil belajar.

\section{THE INFLUENCE OF INQUIRY LEARNING MODEL ON CRITICAL THINKING SKILLS AND STUDENT LEARNING OUTCOMES IN PPKn LEARNING}

\begin{abstract}
This research aims to determine the effect of inquiry model on: (1) critical thinking skills and (2) learning outcomes in learning civic education of thr students of SMA Negeri 3 Lumajang. This research is a quasi experiment. The data were collected through observation and test.the data were analyzed by using the t-test. The result of this research are as follows. (1) There is a significant effect of inquiry model in critical thinking skill in learning civic education of the students of SMA Negeri 3 Lumajang on the basic competence "analyze indicators of threats to the country in building national integration with unity in diversity". (2) There is a significant effect of inquiry model on the learning outcomes in learning civic education of the students of SMA Negeri 3 Lumajang on basic the competence "analyze indicators of threats to the country in building national integration with unity in diversity".
\end{abstract}

Keywords: inquiry, critical thinking skills, outcomes 


\section{Pendahuluan}

PPKn mempunyai peranan penting sebagai wahana untuk mengembangkan kemampuan keterampilan berpikir kritis peserta didik. Dalam mencapai hal tersebut, perlu dikembangkan dan ditransformasikan ke dalam bentuk model pembelajaran yang inovatif yaitu model pembelajaran inkuiri dan model pembelajaran berbasis masalah (problem-based learning). Hal ini sejalan dengan pembelajaran PPKn pada Kurikulum 2013 dimana peserta didik aktif, kooperatif, dan kritis sehingga mampu menghantarkan peserta didik kepada pengalamanpengalaman dan praktik konsep-konsep kehidupan berbangsa dan bernegara dalam ruang kelas dan luar kelas (Samsuri, 2013, pp. 6-7).

Untuk mendorong kemampuan keterampilan berpikir kritis peserta didik untuk mencapai hasil yang maksimal atau kontekstual, baik secara individu maupun kelompok maka sangat disarankan menggunakan model pembelajaran yang menghasilkan karya berbasis pemecahan masalah yang terjadi dalam pembelajaran PPKn. Keterampilan berpikir kritis tergantung pada perilaku berkarakter yang dimiliki siswa (Puskur, 2010, p. 3).

Model pembelajaran inkuiri akan dapat menjembatani atau memberi solusi terhadap pembelajaran PPKn di sekolah yang masih menyimpan berbagai persoalan mengenai model pembelajaran yang diterapkan. Diharapkan dengan adanya model pembelajaran yang sesuai dengan pembalajaran PPKn untuk keterampilan berpikir kritis dan hasil belajar pesera didik dalam upaya penyelesaian isu-isu kontroversial dengan baik dan menjadi warga negara yang cerdas dan baik.

Tujuan PPKn salah satunya adalah untuk mengembangkan partisipasi yang bermutu dan bertanggung jawab dalam kehidupan politik dan masyarakat baik pada tingkat lokal, nasional, maupun global, yang memerlukan penguasaan sejumlah kompetensi kewarganegaraan. Terdapat tiga komponen yang dipelajari dan dikembangkan dalam pembelajaran PPKn yaitu (1). civic knowledge, (2). civic skills, dan (3). civic dispositions (Samsuri, 2006, p. 35).

Tuntutan kualitas pembelajaran, diperlukan sebuah inovasi dalam merancang dan melaksanakan pembelajaran. Salah satunya dengan merancang dan melaksanakan model pembelajaran yang mampu memenuhi tuntutan kebutuhan peserta didik. Model pembelajaran dengan mendiskusikan isu-isu aktual diharapkan menjadi salah satu upaya untuk memenuhi tuntutan kebutuhan peserta didik, yang meliputi tuntutan kebutuhan belajar peserta didik (kelompok maupun individu), dan tuntutan dinamika eksternal. Untuk itu, dibutuhkan model pembelajaran yang sesuai dengan kebutuhan tersebut.

Dalam pembelajaran PPKn, sangat dibutuhkan adanya pemecahan masalah yang berkaitan dengan pelajaran PPKn sehingga peserta didik dapat menggali informasi dari segala aspek sumber atau informasi yang berkaitan dengan pemecahan masalah. Peserta didik dituntut untuk dapat mengembangkan keterampilan berpikir kritis, sehingga akan tercipta suasana belajar yang menyenangkan, dan dapat memberikan suatu pelajaran yang baik bagi peserta didik. Peserta didik dapat mencari informasi dari berbagai sumber atau literatur yang dapat meningkatkan keterampilan berpikir kritis dan hasil belajar peserta didik.

Peserta didik dituntut lebih aktif dalam menggali segala informasi yang berkaitan dengan materi yang diajarkan, sehingga dapat diperoleh hasil belajar yang diinginkan. Guru mengetahui apakah peserta didik sudah mempunyai peningkatan dalam keterampilan berpikir kritis dan dapat dilihat atau diukur dari hasil belajar yang diteliti peserta didik.

Melalui model pembelajaran inkuiri, secara langsung akan membangkitkan kemampuan atau keterampilan berpikir kritis peserta didik dalam menanggapi permasalahan, baik yang bersifat individu maupun kelompok. Selain itu, untuk mengetahui kemampuan peserta didik yang akan dikembangkan, yaitu keterampilan berpikir kritis dan hasil belajar. Dengan demikian, peserta didik tidak hanya tahu teori, tetapi juga dapat mengimplementasikan teori yang didapat dalam kehidupan sehari-hari.

Menurut Hamdayama (2014, p. 31), inkuiri berasal dari kata to inqueri (inquiry) yang berarti ikut serta atau terlibat, dalam mengajukan pertanyaan-pertanyaan, mencari informasi, dan melakukan penyelidikan. Model pembelajaran inkuiri adalah rangkaian kegiatan pembelajaran yang menekankan pada proses berfikir secara kritis dan analisis untuk mencari dan menemukan sendiri jawaban dari suatu masalah yang dipertanyakan.

Kelebihan dari model pembelajaran inkuiri Shoimin (2014, pp. 86-87), yaitu sebagai 
berikut: (a) merupakan strategi pembelajaran yang menekankan kepada pengembangan aspek kognitif, afektif, dan psikomotor secara seimbang sehingga pembelajaran dengan strategi ini dianggap lebih bermakna., (b) dapat memberikan ruang bagi peserta didik untuk belajar sesuai dengan gaya belajar mereka., (c) merupakan strategi yang dianggap sesuai dengan perkembangan psikologi belajar modern yang menganggap belajar adalah proses perubahan tingkah laku berkat adanya pengalaman., (d) dapat melayani kebutuhan peserta didik yang memiliki kemampuan di atas rata-rata.

Hasil dari pra-observasi pada tanggal 24 desember 2015 pada salah satu guru mata pelajaran PPKn di SMA Negeri 3 Lumajang, memberikan penjelasan bahwa: fakta di lapangan menunjukkan belum semua guru memahami dan menerapkan model pembelajaran inkuiri disebabkan kurangnya keinginan dan motivasi untuk meningkatkan kualitas keilmuan maupun kurangnya fasilitas yang memadai dalam proses pembelajaran. Paradigma yang perlu dibangun adalah guru bertindak sebagai fasilitator, bukan sebagai satu-satunya sumber belajar di kelas. Guru harus mempunyai banyak inovasi pembelajaran yang membuat peserta didik akan meninggkatkan keterampilan berpikir kritis dalam menanggapi isu yang terkait dengan kehidupan sehari-hari.

Model pembelajaran inkuiri digunakan untuk meningkatkan keterampilan berpikir kritis dan hasil belajar. Selama ini model pembelajaran PPKn yang digunakan cenderung monoton, sehingga kurang menarik nimat peserta didik untuk mengikuti pembelajaran PPKn. Guru dituntut untuk dapat melakukan inovasi model pembalajaran yang menyenangkan dan menarik minat peserta didik agar dapat meningkatkan keterampilan berpikir kritis dan hasil belajar.

Hasil belajar peserta didik dapat diukur melalui kemampuan peserta didik pada saat proses pembelajaran berlangsung. Selain itu, hasil belajar peserta didik ini juga akan mempengaruhi keterampilan berpikir kritis peserta didik yang dimana akan banyak menggali informasi dari berbagai sumber sehingga dalam hasil belajar peserta didik akan terlihat secara signifikan dalam kemampuan untuk meningkatkan keterampilan berpikir kritis.

Hasil belajar peserta didik dalam pembelajaran PPKn kurang signifikan. Karena guru hanya menggunakan model pembelajaran yang sama setiap pembelajaran di kelas, sehingga peserta didik merasa bosan dengan model pembelajaran yang digunakan. Seharusnya guru mempunyai inovasi yang lebih menarik untuk meningkatkan hasil belajar peserta didik. Hasil belajar peserta didik mencapai $83 \%$ nilai yang kurang dari standar kriteria ketuntasan minimal yaitu 73, yang terdiri dari jumlah peserta didik dalam satu kelas yaitu berjumlah 34 peserta didik. Kegiatan pembelajaran di kelas peserta didik cenderung pasif sedangkan guru yang lebih aktif, sehingga hasil belajar peserta tidak maksimal.

Winkel (Purwanto, 2014, pp. 39), Belajar adalah aktivitas mental atau psikis yang berlangsung dalam interaksi aktif dengan lingkungan yang menghasilkan perubahan-perubahan dalam pengetahuan, keterampilan dan sikap. Belajar merupakan proses yang disengaja untuk mengubah tingkah laku peserta didik ke arah tujuan yang telah ditetapkan.

Pendapat sama dikemukakan Newby (2000, p. 8) mendefinisikan "learning occors when experience couse a relatively permanent change in an individual's knowledge or behavior". Dengan balajar akan mengakibatkan perubahan pengetahuan individu dan prilaku secara permanen.

Penelitian ini memiliki tujuan sebagai berikut. (1) Mengetahui pengaruh penerapan model pembelajaran inkuiri terhadap keterampilan berpikir kritis peserta didik dalam pembelajaran PPKn di SMA Negeri 3 Lumajang, dan (2) mengetahui pengaruh penerapan model pembelajaran inkuiri dalam pembelajaran PPKn terhadap hasil belajar peserta didik di SMA Negeri 3 Lumajang.

\section{Metode Penelitian}

Jenis penelitian yang dilakukan oleh peneliti adalah quasi eksperiment atau eksperiman semu. Desain penelitian berbentuk randomized control group pretest-posttest design ini dapat dilihat pada Tabel 1.

Tabel 1. Kelas Eksperimen dan Kelas Kontrol

\begin{tabular}{cccc}
\hline Kelas & Pretest & Treatment & Posttest \\
\hline Eksperimen & $\mathrm{T}_{1}$ & $\mathrm{X}_{1}$ & $\mathrm{~T}_{2}$ \\
Kontrol & $\mathrm{T}_{1}$ & $\mathrm{X}_{2}$ & $\mathrm{~T}_{2}$ \\
\hline
\end{tabular}


Keterangan:

$\mathrm{T}_{1}=$ Nilai pretest

$\mathrm{T}_{2}=$ Nilai posttest

$\mathrm{X}_{1}=$ Kelas eksperimen dengan menggunakan model pembelajaran inkuiri

$\mathrm{X}_{2}=$ Kelas kontrol dengan menggunakan model pembelajaran berbasis masalah.

Penelitian ini dilaksanakan di SMA Negeri 3 Lumajang yang beralamat di Jalan Jenderal Panjaitan No. 79 Lumajang, Jawa Timur. Pelaksanaan penelitian pada bulan Januari sampai dengan Maret 2016 pada Semester Genap Tahun Pelajaran 2015/2016 dengan memberikan perlakuan sebanyak 4 kali pada Kompetensi Dasar menganalisis indikator ancaman terhadap negara dalam membangun integrasi nasional dengan Bhineka Tunggal Ika.

Populasi dalam penelitian ini adalah seluruh peserta didik kelas X SMA Negeri 3 Lumajang tahun pelajaran 2015/2016 yang terdiri dari beberapa jurusan. Jurusan tersebut yaitu IPA dan IPS yang masing-masing jurusan menjadi 3 kelas dan 2 kelas yaitu IPS 1,IPS 2, IPS 3 dan IPA 1, IPA 2.

Teknik yang digunakan dalam pengambilan sampel dilakukan secara acak berdasarkan kriteria pada kelas yang dijadikan sebagai kelas eksperimen dan kelas kontrol, alasan peneliti untuk melaksanakan penelitian di SMA Negeri 3 Lumajang.

Instrumen pengumpulan data yang digunakan sebagai berikut. (1) Observasi, untuk mengukur keterampilan berpikir kritis peserta didik sebelum dan setelah diberikan perlakuan pada kelas eksperimen yang diajar menggunakan model pembelajaran inkuiri maupun kelas kontrol yang diajar menggunakan model pembelajaran berbasis masalah (problem-basic learning). (2) Tes, yang digunakan berupa tes tertulis yang berbentuk pilihan ganda yang berjumlah 50 butir soal dengan 5 alternatif jawaban a, b, c, d, dan e.

Analisis data yang digunakan adalah analisis uji-t. Sebelum dilakukan uji-t terlebih dahulu dilakukan uji prasyarat analisis data yaitu uji normalitas dan uji homogenitas. Jika kedua kelas distribusi normal dan homogen, maka dilakukan uji-t dengan bantuan software SPSS 16.0 foe windows.

Kriteria pengujian, antara lain. (1) Jika $\mathrm{t}_{\text {hitung }}<\mathrm{t}_{\text {tabel }}$, maka tidak terdapat perbedaan antara peserta didik yang diajar dengan menggunakan model pembelajaran inkuiri dengan peserta didik yang diajar menggunakan model pembelajaran berbasis masalah (problembased learning). (2) Jika nilai $\mathrm{t}_{\text {hitung }}>\mathrm{t}_{\text {tabel}}$, maka terdapat perbedaan antara peserta didik yang diajar dengan menggunakan model pembelajaran inkuiri dengan peserta didik yang diajar dengan menggunakan model pembelajaran berbasis masalah (problem-based learning).

\section{Hasil Penelitian dan Pembahasan}

Sebelum menguji hipotesis dilakukan uji prasyarat analisis data yaitu uji normalitas dan uji homogenitas. Uji normalitas variabel dilakukan dengan menggunakan uji kolmogorov smirnov. Kriteria penerimaan normalitas adalah jika nilai signifikansi hasil perhitungan lebih besar dari $\alpha=0,05$ maka distribusinya dikatakan normal, sebaliknya jika lebih kecil dari $\alpha=0,05$ maka distribusinya dikatakan tidak normal. Di bawah ini disajikan hasil perhitungan untuk semua variabel pada Tabel 2.

Tabel 2. Rangkuman Hasil Uji Normalitas

\begin{tabular}{|c|c|c|c|}
\hline No & Data & $\operatorname{Sig}(\mathrm{p})$ & Keterangan \\
\hline 1 & Pretest ekspe & 834 & $\begin{array}{l}\text { Signifikansi }> \\
0,05=\text { normal }\end{array}$ \\
\hline 2 & Postes & 0,344 & $\begin{array}{l}\text { Signifikansi }> \\
0,05=\text { normal }\end{array}$ \\
\hline 3 & Pretest eksperimen 2 & 0,837 & $\begin{array}{l}\text { Signifikansi }> \\
0,05=\text { normal }\end{array}$ \\
\hline 4 & Pos & 0,824 & $\begin{array}{l}\text { Signifi } \\
0,05=\end{array}$ \\
\hline 5 & Prete & ,174 & \\
\hline 6 & Pos & 579 & $\begin{array}{l}\text { Signifikansi }> \\
0,05=\text { normal }\end{array}$ \\
\hline 7 & $\begin{array}{l}\text { Ketel } \\
\text { kritis }\end{array}$ & 0,141 & $\begin{array}{l}\text { Signifikansi }> \\
0,05=\text { normal }\end{array}$ \\
\hline 8 & $\begin{array}{l}\text { Keterampilan berpikir } \\
\text { kritis eksperimen } 2\end{array}$ & 0,927 & $\begin{array}{l}\text { Signifikansi }> \\
0,05=\text { normal }\end{array}$ \\
\hline 9 & $\begin{array}{l}\text { Keterampilan berpikir } \\
\text { kritis control }\end{array}$ & 0,608 & $\begin{array}{l}\text { Signifikansi }> \\
0,05=\text { normal }\end{array}$ \\
\hline
\end{tabular}

(Sumber: Data primer yang diolah, 2016)

Berdasarkan hasil perhitungan program SPSS, dapat diketahui bahwa sebaran data normal. Dari hasil perhitungan normalitas dalam penelitian ini berdistribusi normal, karena mempunyai nilai signifikansi lebih besar dari 0,05 pada $(p>0,05)$. Jadi, data ini telah memenuhi syarat untuk dianalisis.

Setelah dilakukan uji normalitas sebaran data, selanjutnya dilakukan uji homo- 
genitas. Dengan bantuan program SPSS, dihasilkan skor yang menunjukkan varians yang homogen. Syarat agar varians dikatakan homogen apabila signifikan lebih besar dari 0,05 atau $F_{\text {hitung }}<F_{\text {tabel }}$. Di bawah ini disajikan hasil uji homogenitas pada Tabel 3.

Tabel 3. Rangkuman Hasil Uji Homogenitas Varians

\begin{tabular}{|c|c|c|c|c|c|c|}
\hline $\mathrm{Nc}$ & Data & Fhitung & Ftabel & $\mathrm{db}$ & Sig & Keterangan \\
\hline 1 & $\begin{array}{l}\text { Hasil Belajar } \\
\text { Eksperimen } 1 \\
\text { dengan Kontrol }\end{array}$ & 1,767 & 4,00 & $1: 60$ & 0,189 & Homogen \\
\hline 2 & $\begin{array}{l}\text { Hasil Belajar } \\
\text { Eksperimen } 2 \\
\text { dengan Kontrol }\end{array}$ & 0,143 & & $1: 59$ & 0,707 & Homogen \\
\hline 3 & $\begin{array}{l}\text { Keterampilan } \\
\text { berfikir kritis } \\
\text { Eksperimen } 1 \\
\text { dengan Kontrol }\end{array}$ & 0,934 & & $1: 60$ & 0,338 & Homogen \\
\hline 4 & $\begin{array}{l}\text { Keterampilan } \\
\text { berfikir kritis } \\
\text { Eksperimen } 2 \\
\text { dengan Kontrol }\end{array}$ & 1,034 & & $1: 59$ & 0,313 & Homogen \\
\hline
\end{tabular}

(Sumber: Data primer yang diolah, 2014).

Dari hasil perhitungan uji homogenitas variabel dengan program SPSS dalam penelitian ini menunjukkan bahwa data tersebut mempunyai varians yang homogen, karena nilai signifikansi lebih besar dari $5 \%(p>0,05)$ atau memiliki $F_{\text {hitung }}<F_{\text {tabel }}$. Jadi, data tersebut telah memenuhi syarat untuk dianalisis.

Hipotesis pertama dalam penelitian ini adalah "penerapan model pembelajaran inkuiri dalam pembelajaran PPKn berpengaruh terhadap keterampilan berpikir kritis peserta didik dalam pembelajaran PPKn di SMA Negeri 3 Lumajang". Analisis yang digunakan adalah Analisis uji-t dengan bantuan program SPSS. Syarat data bersifat signifikan apabila $p$ lebih kecil dari 0,05. Di bawah ini disajikan hasil ujit keterampilan berfikir kritis peserta didik kelas eksperimen 1 dengan kelas kontrol pada tabel 4.

Tabel 4 menunjukkan bahwa besar $t_{\text {hitung }}$ adalah 3,058 dan nilai $t_{\text {tabel }}$ dengan $\mathrm{db}$ 60 pada taraf signifikansi $1 \%$ sebesar 2,000. nilai $t_{\text {hitung }}>t_{\text {tabel }}$, atau Nilai $p$ lebih kecil dari $0,01(\mathrm{p}=0,003<0,01)$. Dengan demikian hasil uji-t tersebut menunjukkan terdapat perbedaan yang signifikan keterampilan berpikir kritis peserta didik dalam pembelajaran PPKn di SMA Negeri 3 Lumajang antara yang menggunakan model pembelajaran inkuiri (kelas eksperimen 1) dengan model pembelajaran problem basic learning (kelompok kontrol). Dengan adanya perbedaan tersebut menunjukkan hipotesis diterima, yakni penerapan model pembelajaran inkuiri dalam pembelajaran PP$\mathrm{Kn}$ berpengaruh terhadap keterampilan berpikir kritis peserta didik dalam pembelajaran PPKn di SMA Negeri 3 Lumajang.

Tabel 4. Rangkuman Hasil Uji-t Keterampilan Berfikir Kritis Peserta Didik Kelas Eksperimen 1 dengan Kelas Kontrol.

\begin{tabular}{|c|c|c|c|c|}
\hline Data & Mean Sig & t hitung & $\mathrm{t}$ tabel & Keterangan \\
\hline $\begin{array}{l}\text { Ekperimen } 1 \\
\text { (model inkuiri) }\end{array}$ & $46,21 \quad 0,003$ & 3,058 & 2,000 & $\begin{array}{l}\text { Sangat } \\
\text { Signifikan }\end{array}$ \\
\hline $\begin{array}{l}\text { Kontrol } \\
\text { (model PBL) }\end{array}$ & 40,76 & & & $\begin{array}{l}(\mathrm{P}:=0,003 \\
<0,01)\end{array}$ \\
\hline
\end{tabular}

(Sumber: Data primer yang diolah, 2016).

Di bawah ini disajikan hasil uji-t keterampilan berfikir kritis peserta didik kelas eksperimen 2 dengan kelas kontrol pada Tabel 5.

Tabel 5. Rangkuman Hasil Uji-t

Keterampilan Berfikir Kritis Peserta

Didik Kelas Eksperimen 2 dengan Kelas Kontrol

\begin{tabular}{llllll}
\hline Data & Mean & Sig & t hitung t tabel & Keterangan \\
\hline $\begin{array}{l}\text { Ekperimen 2 } \\
\text { (model }\end{array}$ & 47,61 & 0.000 & 4,245 & 2,000 & $\begin{array}{l}\text { Sangat } \\
\text { inkuiri) }\end{array}$ \\
ingifikan & \\
$\begin{array}{l}\text { Kontrol } \\
\text { (model PBL) }\end{array}$ & 40,75 & & & & $(\mathrm{P}:=0,000<$ \\
\hline
\end{tabular}

(Sumber: Data primer yang diolah, 2016).

Dari Tabel 5 juga dapat diketahui nilai $t_{\text {hitung }}$ adalah 4,245 dan nilai $t_{\text {tabel }}$ dengan db 60 pada taraf signifikansi $1 \%$ sebesar 2,000. nilai $t_{\text {hitung }}>t_{\text {tabel }}$, atau Nilai $\mathrm{p}$ lebih kecil dari $0,01(p=0,000<0,01)$. Dengan demikian hasil uji-t tersebut menunjukkan terdapat perbedaan yang signifikan keterampilan berpikir kritis peserta didik dalam pembelajaran PPKn di SMA Negeri 3 Lumajang antara yang menggunakan model pembelajaran inkuiri (kelas eksperimen 2) dengan model pembelajaran problem basic learning (kelompok kontrol). Dengan adanya perbedaan tersebut menunjukkan hipotesis diterima, yakni penerapan model pembelajaran inkuiri dalam pembelajaran PP$\mathrm{Kn}$ berpengaruh terhadap keterampilan berpi- 
kir kritis peserta didik dalam pembelajaran PPKn di SMA Negeri 3 Lumajang.

Berdasarkan hasil yang telah diuraikan sebelumnya menunjukkan bahwa kelas eksperimen 1 dan 2 yang sama-sama menggunakan model pembelajaran inkuiri berpengaruh terhadap keterampilan berpikir kritis peserta didik dalam pembelajaran PPKn di SMA Negeri 3 Lumajang. Efektivitas tersebut juga dapat dilihat pada hasil gain score yang disajikan pada Tabel 6.

Tabel 6. Hasil Gain Score Keterampilan Berpikir Kritis

\begin{tabular}{lll}
\hline Kelas & $\begin{array}{l}\text { Gain } \\
\text { Score }\end{array}$ & Kategori \\
\hline Eksperimen 1 (model inkuiri) & 0.72 & Efektivitas tinggi \\
Eksperimen 2 (model inkuiri) & 0.74 & Efektivitas tinggi \\
Kontrol (model PBL) & 0.64 & Efektivitas sedang \\
\hline
\end{tabular}

(Sumber: Data primer yang diolah, 2016).

Tabel 6 tersebut menunjukkan bahwa pada peserta didik kelas eksperimen 1 dengan model inkuiri memperoleh gain score sebesar 0.72 dalam kategori efektivitas tinggi. Kemudian pada kelas eksperimen 2 yang juga menggunakan model pembelajaran inkuiri memperoleh skor 0.74 dalam kategori efektivitas tinggi. Sementara pada kelas kontrol yang menggunakan model pembelajaran problem basic learning memperoleh gain score sebesar 0.64 dalam kategori efektivitas sedang.

Dengan demikian dapat disimpulkan bahwa hipotesis pertama dalam penelitian ini diterima yaitu penerapan model pembelajaran inkuiri dalam pembelajaran PPKn berpengaruh terhadap keterampilan berpikir kritis peserta didik dalam pembelajaran PPKn di SMA Negeri 3 Lumajang. Hal ini ditunjukkan dari nilai signifikansi lebih kecil dari 0,05 dan hasil gain score.

Hipotesis kedua dalam penelitian ini adalah "penerapan model pembelajaran inkuiri dalam pembelajaran PPKn berpengaruh terhadap peningkatan hasil belajar peserta didik dalam pembelajaran PPKn di SMA Negeri 3 Lumajang". Analisis uj-t dengan bantuan program SPSS. Syarat data bersifat signifikan apabila $p$ lebih kecil dari 0,05 . Di bawah ini disajikan hasil uji-t hasil belajar peserta didik dalam pembelajaran PPKn kelas eksperimen 1 dengan kelas kontrol pada Tabel 7.

Dari Tabel 7 dapat diketahui nilai $t_{\text {hitung }}$ adalah 4,498 dan nilai $t_{\text {tabel }}$ dengan $\mathrm{db}$
60 pada taraf signifikansi $1 \%$ sebesar 2,000. nilai $t_{\text {hitung }}>t_{\text {tabel }}$, atau Nilai p lebih kecil dari $0,01(\mathrm{p}=0,000<0,01)$. Dengan demikian hasil uji-t tersebut menunjukkan terdapat perbedaan yang signifikan hasil belajar peserta didik dalam pembelajaran PPKn di SMA Negeri 3 Lumajang antara yang menggunakan model pembelajaran inkuiri (kelas eksperimen 1) dengan model pembelajaran problem basic learning (kelompok kontrol). Dengan adanya perbedaan tersebut menunjukkan hipotesis diterima, yakni penerapan model pembelajaran inkuiri dalam pembelajaran PPKn berpengaruh terhadap hasil belajar peserta didik dalam pembelajaran PPKn di SMA Negeri 3 Lumajang.

Tabel 7. Rangkuman Hasil Uji-t Hasil Belajar Peserta Didik Dalam Pembelajaran PPKn Kelas Eksperimen 1 dengan Kelas Kontrol

\begin{tabular}{|c|c|c|c|c|}
\hline Data & Mean Sig & t hitung & $\mathrm{t}$ tabel & Keterangan \\
\hline $\begin{array}{l}\text { Ekperimen } 1 \\
\text { (model inkuiri) }\end{array}$ & $62,97 \quad 0,000$ & 4,498 & 0,000 & $\begin{array}{l}\text { Sangat } \\
\text { Signifikan }\end{array}$ \\
\hline $\begin{array}{l}\text { Kontrol } \\
\text { (model PBL) }\end{array}$ & 52.61 & & & $\begin{array}{l}(\mathrm{P}:=0,000< \\
0,01)\end{array}$ \\
\hline
\end{tabular}

(Sumber: Data primer yang diolah, 2016).

Di bawah ini disajikan hasil uji-t hasil belajar peserta didik dalam pembelajaran PPKn kelas eksperimen 2 dengan kelas kontrol pada tabel 8 .

Tabel 8. Rangkuman Hasil Uji-t Hasil Belajar Peserta didik Kelas Eksperimen 2 dengan Kelas Kontrol

\begin{tabular}{|c|c|c|c|c|}
\hline Data & Mean Sig & t hitung & $\mathrm{t}$ tabel & Keterangan \\
\hline $\begin{array}{l}\text { Ekperimen } 2 \\
\text { (model inkuiri) }\end{array}$ & $63,43 \quad 0.000$ & 5,349 & 2,000 & $\begin{array}{l}\text { Sangat } \\
\text { Signifikan }\end{array}$ \\
\hline $\begin{array}{l}\text { Kontrol } \\
\text { (model PBL) }\end{array}$ & 52,61 & & & $\begin{array}{l}(\mathrm{P}:=0,000< \\
0,01)\end{array}$ \\
\hline
\end{tabular}

(Sumber: Data primer yang diolah, 2016).

Dari Tabel 8 juga dapat diketahui nilai $t_{\text {hitung }}$ adalah 5,349 dan nilai $t_{\text {tabel }}$ dengan $\mathrm{db}$ 59 pada taraf signifikansi $1 \%$ sebesar 2,000. nilai $t_{\text {hitung }}>t_{\text {tabel }}$, atau Nilai $p$ lebih kecil dari $0,01(\mathrm{p}=0,000<0,01)$. Dengan demikian hasil uji-t tersebut menunjukkan terdapat perbedaan yang signifikan hasil belajar peserta didik dalam pembelajaran PPKn di SMA Negeri 3 Lumajang antara yang menggunakan model pembelajaran inkuiri (kelas eksperimen 2) dengan model pembelajaran problem basic learning (kelompok kontrol). Dengan adanya 
perbedaan tersebut menunjukkan hipotesis diterima, yakni penerapan model pembelajaran inkuiri dalam pembelajaran PPKn berpengaruh terhadap hasil belajar peserta didik dalam pembelajaran PPKn di SMA Negeri 3 Lumajang.

Berdasarkan hasil yang telah diuraikan sebelumnya menunjukkan bahwa kelas eksperimen 1 dan 2 yang sama-sama menggunakan model pembelajaran inkuiri berpengaruh terhadap peningkatan hasil belajar peserta didik dalam pembelajaran PPKn di SMA Negeri 3 Lumajang. Efektivitas tersebut juga dapat dilihat pada hasil gain score yang disajikan pada Tabel 9.

Tabel 9. Hasil Gain Score Hasil Belajar

\begin{tabular}{lcl}
\hline Kelas & $\begin{array}{c}\text { Gain } \\
\text { Score }\end{array}$ & Kategori \\
\hline Eksperimen 1 (model inkuiri) & 0,31 & Efektivitas sedang \\
Eksperimen 2 (model inkuiri) & 0,31 & Efektivitas sedang \\
Kontrol (model PBL) & 0,06 & Efektivitas rendah \\
\hline
\end{tabular}

(Sumber: Data primer yang diolah, 2016).

Tabel 9 tersebut menunjukkan bahwa baik pada peserta didik kelas eksperimen 1 maupun peserta didik kelas eksperimen 2 dengan model inkuiri memperoleh gain score sebesar 0.31 dalam kategori efektivitas sedang Sementara pada kelas kontrol yang menggunakan model pembelajaran problem basic learning memperoleh gain score sebesar 0.06 dalam kategori efektivitas rendah.

Dengan demikian dapat disimpulkan bahwa hipotesis kedua dalam penelitian ini diterima yaitu penerapan model pembelajaran inkuiri dalam pembelajaran PPKn berpengaruh terhadap hasil belajar peserta didik dalam pembelajaran PPKn di SMA Negeri 3 Lumajang. Hal ini ditunjukkan dari nilai signifikansi lebih kecil dari 0,05 dan hasil gain score.

Dari hasil analisis data diketahui bahwa pengaruh model pembelajaran inkuiri dalam pembelajaran PPKn berpengaruh terhadap keterampilan berpikir kritis peserta didik dalam pembelajaran PPKn di SMA Negeri 3 Lumajang. Hal ini ditunjukkan dari nilai signifikansi lebih kecil dari 0,05 dan hasil gain score. Pada kelas eksperimen 1 dengan kelas kontrol nilai $t_{\text {hitung }}>t_{\text {tabel }}(3,058>2,000)$ atau nilai $\mathrm{p}$ lebih kecil dari $0,01(\mathrm{p}=0,003<0,01)$. Sementara kelas eksperimen 2 dengan kelas kontrol memiliki nilai $t_{\text {hitung }}>t_{\text {tabel }}(4,245>$ $2,000)$ atau nilai $\mathrm{p}$ lebih kecil dari $0,01(\mathrm{p}=$ $0,000<0,01)$.
Peserta didik kelas eksperimen 1 dengan model inkuiri memperoleh gain score sebesar 0.72 dalam kategori efektivitas tinggi. Kemudian pada kelas eksperimen 2 yang juga menggunakan model pembelajaran inkuiri memperoleh skor 0.74 dalam kategori efektivitas tinggi. Sementara pada kelas kontrol yang menggunakan model pembelajaran problem basic learning memperoleh gain score sebesar 0.64 dalam kategori efektivitas sedang. Hasil perbandingan gain score dapat dilihat pada Gambar 1.

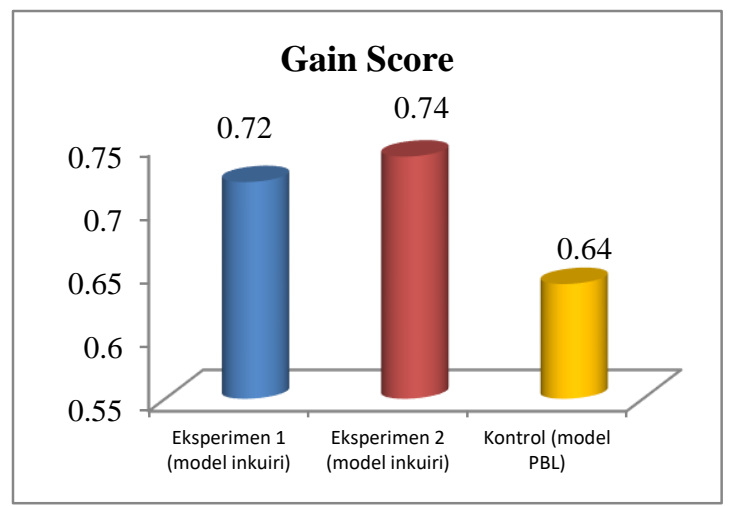

Gambar 1. Perbandingan Peroleh Gain Score Keterampilan Berpikir Kritis.

Hasil perbandingan mean (skor ratarata) juga menunjukkan peserta didik kelas eksperimen 1 dan kelas eksperimen 2 yang menggunakan model pembelajaran inkuiri lebih memperoleh skor yang lebih tinggi dibandingkan kelas kontrol yang menggunakan model pembelajaran problem basic learning. Peserta didik kelas eksperimen 1 memperoleh skor mean sebesar 46.21, kelas eksperimen 2 memperoleh skor mean 47,61 dan kelas kontrol sebesar 40.75. Hasil perbandingan peroleh skor mean keterampilan berpikir kritis dapat dilihat pada Gambar 2.

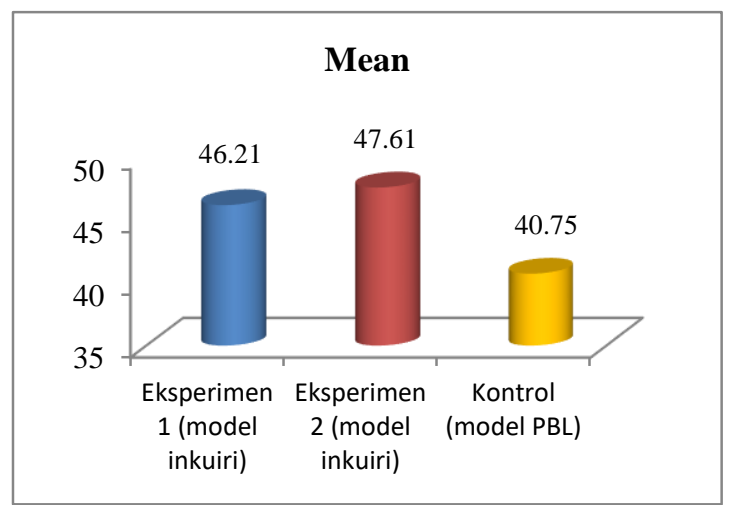

Gambar 2. Perbandingan Peroleh Skor Mean Keterampilan Berpikir Kritis

Harmoni Sosial Jurnal Pendidikan IPS Volume 4, No 2, September 2017 
Hasil penelitian ini menguatkan penelitian sebelumnya yang dilakukan oleh Ibrahim (2012) dengan judul Pengaruh Metode Inkuiri dan Pemberian Tugas Terhadap Aktivitas dan Pemahaman Konsep Sains Peserta didik Kelas VII SMP Negeri 1 Orong Telu Kabupaten Sumbawa-NTB. Hasil penelitian menunjukkan bahwa penerapan metode inkuiri dalam pembelajaran sains dapat meningkatkan aktivitas dan pemahaman konsep sains peserta didik kelas VII SMP Negeri 1 Orong Telu Kabupaten Sumbawa-NTB secara signifikan dan penerapan metode inkuiri dan pemberian tugas dalam pembelajaran sains mempunyai perbedaan yang signifikan dalam meningkatkan aktivitas dan pemahaman konsep sains peserta didik kelas VII SMP Negeri 1 Telu Kabupaten Sumbawa-NTB. Hasil penelitian ini juga sesuai dengan pendapat Hamdayama (2014, p. 31) bahwa model pembelajaran inkuiri merupakan model pembelajaran yang menekankan pada proses berfikir secara kritis dan analitis untuk mencari dan menemukan sendiri jawaban dari suatu masalah yang dipertanyakan.

Model pembelajaran inkuiri adalah sebuah pendekatan dalam pelajaran yang mengharapkan peserta didik menemukan dan menggunakan berbagai sumber informasi dan ideide untuk meningkatkan pemahaman peserta didik tentang topik masalah-masalah atau membutuhkan lebih banyak lagi dari sekedar menjawab pertanyaan atau mendapatkan jawaban yang benar. Hal ini menjadikan model pembelajaran inkuiri secara langsung membangkitkan kemampuan atau keterampilan berpikir kritis peserta didik dalam menanggapi permasalahan, baik yang bersifat individu maupun kelompok.

Sementara model pembelajaran problem basic learning pada kelas kontrol tampak peserta didik kurang memahami tentang alasan masalah-masalah yang harus dipecahkan dan peserta didik kurang percaya diri dalam memecahkan masalah, sehingga motivasi belajar juga menjadi kurang maksimal, sehingga berdampak pula pada peningkatan keterampilan berpikir kritis yang kurang maksimal. Hal ini sesuai dengan pendapat Shoimin (2014, pp. 8687) bahwa model pembelajaran inkuiri dianggap pembelajaran yang lebih bermakna karena menekankan pada pengembangan aspek kognitif, afektif, dan psikomotor secara seimbang.

Hasil temuan lainnya juga menunjukkan bahwa mayoritas kecenderungan keteram- pilan berpikir kritis pada peserta didik kelas eksperimen 1 yang menggunakan model pembelajaran inkuiri dalam kategori baik sebesar $58,6 \%$. Demikian pula dengan kelas eksperimen 2 yang menggunakan model pembelajaran inkuiri menunjukkan mayoritas kecenderungan keterampilan berpikir kritis pada kategori baik sebesar $42,9 \%$. Sementara pada kelas kontrol yang menggunakan model pembelajaran problem basic learning menunjukkan mayoritas kecenderungan keterampilan berpikir kritis pada kategori cukup sebesar 60,6\%. Hal ini berarti model pembelajaran inkuiri baik pada kelas eksperimen 1 maupun kelas eksperimen 2 lebih baik dibandingkan kelas kontrol yang menggunakan model pembelajaran problem basic learning.

Berdasarkan uraian di atas dapat disimpulkan bahwa penerapan model pembelajaran inkuiri dalam pembelajaran PPKn berpengaruh terhadap keterampilan berpikir kritis peserta didik dalam pembelajaran PPKn di SMA Negeri 3 Lumajang.

Hasil penelitian menunjukkan bahwa penerapan model pembelajaran inkuiri dalam pembelajaran PPKn berpengaruh terhadap hasil belajar peserta didik dalam pembelajaran PPKn di SMA Negeri 3 Lumajang. Hal ini ditunjukkan dari nilai signifikansi lebih kecil dari 0,05 dan hasil gain score. Pada kelas eksperimen 1 dengan kelas kontrol nilai $t_{\text {hitung }}>t_{\text {tabel }}(4,498>2,000)$ atau nilai $\mathrm{p}$ lebih kecil dari 0,01 ( $\mathrm{p}=0,000<0,01)$. Sementara kelas eksperimen 2 dengan kelas kontrol memiliki nilai $t_{\text {hitung }}>t_{\text {tabel }}(5,349>$ $2,000)$ atau nilai $\mathrm{p}$ lebih kecil dari $0,01(\mathrm{p}=$ $0,000<0,01)$.

Peserta didik kelas eksperimen 1 maupun eksperimen 2 dengan model inkuiri memperoleh gain score sebesar 0.31 masingmasing dalam kategori efektivitas sedang. Sementara pada kelas kontrol yang menggunakan model pembelajaran problem basic learning memperoleh gain score sebesar 0.06 dalam kategori efektivitas rendah. Hasil perbandingan gain score dapat dilihat pada gambar 3.

Hasil perbandingan mean (skor ratarata) juga menunjukkan peserta didik kelas eksperimen 1 dan kelas eksperimen 2 yang menggunakan model pembelajaran inkuiri lebih memperoleh skor yang lebih tinggi dibandingkan kelas kontrol yang menggunakan model pembelajaran problem basic learning. Peserta didik kelas eksperimen 1 pada saat pretest 
memperoleh skor mean sebesar 47,10 dan saat postest menjadi 62.97. Kelas eksperimen 2 pada saat pretest memperoleh skor mean 47,50 dan saat postest menjadi 63.43. Sementara kelas kontrol saat pretest sebesar 49.27 dan saat postest menjadi 52.61. Hasil perbandingan mean hasil belajar dapat dilihat pada Gambar 4.

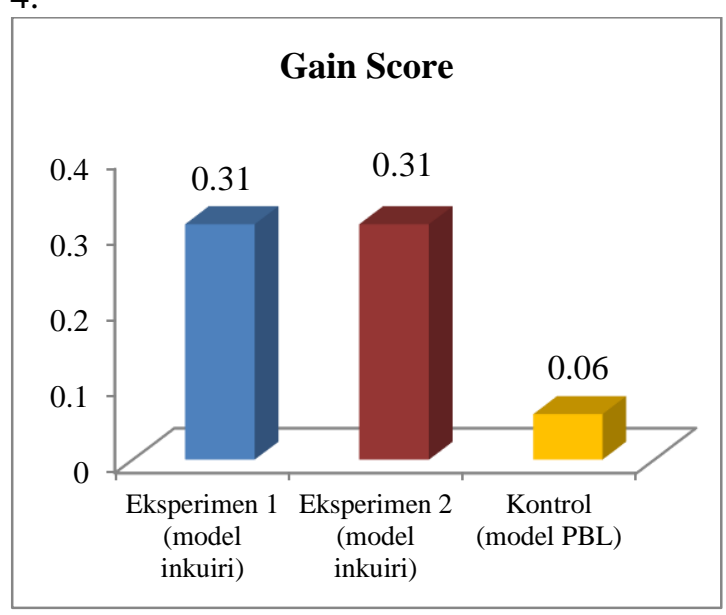

Gambar 3. Perbandingan Peroleh Gain Score Hasil Belajar

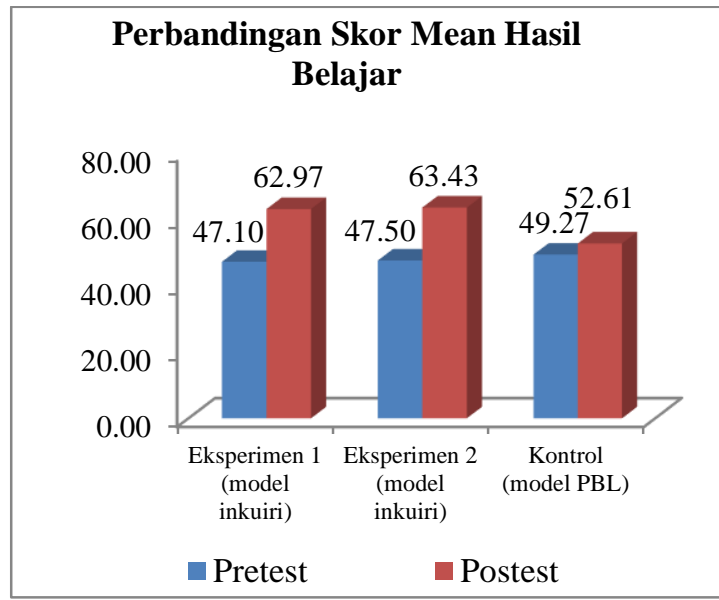

Gambar 4. Perbandingan Peroleh Skor Mean Hasil Belajar

Hasil penelitian ini juga menguatkan penelitian sebelumnya yang dilakukan oleh Taat Wulandari (2009) dengan judul Metode Inkuiri Dalam Pembelajaran IPS (Tesis) yang membuktikan bahwa hasil belajar dengan menggunakan metode inkuiri lebih besar dibanding dengan hasil peserta didik dengan menggunakan metode konvensional. Hal ini ditunjukkan oleh nilai F sebesar 59.040 dengan p sebesar $0.000<0.05$. Selain itu juga sesuai dengan hasil penelitian yang dilakukan oleh Silalahi (2011) dengan judul Kontribusi Model Pembelajaran Kontekstual Tipe Inkuiri Dalam
Memingkatkan Motivasi dan Prestasi Belajar Peserta didik Pada Mata Pelajaran Pendidikan Kewarganegaraan. Hasil penelitiannya menyimpulkan bahwa terdapat perbedaan pada peningkatan moyivasi dan prestasi belajar peserta didik setelah mendapat pembelajaran dengan model pembelajaran kontekstual tipe inkuiri. (2) terdapat perbedaan peningkatan motivasi dan prestasi belajar antara peserta didik yang belajar dengan model pembelajaran konvensional dengan peserta didik yang belajar dengan model pembelajaran kontekstual tipe inkuiri.

Pembelajaran PPKn dalam Kurikulum 2013 menggunakan pendekatan sainstifik, merupakan pembelajaran yang mengadopsi langkah-langkah dalam membangun pengetahuan atau keterampilan melalui metode ilmiah, salah satunya yaitu melalui model inkuiri. Model pembelajaran inkuiri akan dapat menjembatani atau memberi solusi terhadap pembelajaran PPKn di sekolah yang masih menyimpan berbagai persoalan mengenai model pembelajaran yang diterapkan. Hasil penelitian ini membuktikan bahwa model pembelajaran inkuiri berpengaruh terhadap hasil belajar.

Pada kelas eksperimen 1 maupun kelas eksperimen 2 dengan menggunakan model pembelajaran inkuiri tampak bahwa guru memberikan kesempatan belajar untuk memperoleh keterampilan dengan menyajikan situasi nyata, dan untuk menyelidiki dan menyelesaikan masalah yang berkaitan dengan kehidupan nyata. Hal ini tentunya menuntut peserta didik untuk berpikir dan mencari solusi dengan sebuah permasalahan yang diberikan oleh pendidik, serta membuat peserta didik mempunyai pengalaman belajar menjadi suatu yang bermakna dalam kehidupan nyata. Dengan model pembelajaran inkuiri, peserta didik dibiasakan untuk produktif, analitis, dan kritis. Apabila peserta didik aktif dalam menemukan sendiri fakta, konsep, dan generalisasi, maka apa yang telah ditentukan secara langsung tersebut akan senantiasa diingat serta dipahami oleh peserta didik, sehingga hasil belajar menjadi lebih optimal.

Penelitian ini sesuai dengan pendapat Shoimin (2014, pp. 86-87) yang menjelaskan bahwa model pembelajaran inkuiri memiliki banyak keunggulan dibandingkan model pembelajaran lainnya. Keunggulan tersebut antara lain: model pembelajaran inkuiri yang menekankan kepada pengembangan aspek kognitif, 
afektif, dan psikomotor secara seimbang sehingga pembelajaran dengan strategi ini dianggap lebih bermakna serta dapat memberikan ruang bagi peserta didik untuk belajar sesuai dengan gaya belajar peserta didik.

Dengan demikian dapat disimpulkan bahwa penerapan model pembelajaran inkuiri dalam pembelajaran PPKn berpengaruh terhadap peningkatan hasil belajar peserta didik dalam pembelajaran PPKn di SMA Negeri 3 Lumajang. Oleh karena itu, guru perlu menerapkan model pembelajaran inkuiri dalam pembelajaran PPKn. Hal ini dikarenakan model pembelajaran inkuiri sesuai dengan kurikulum saat ini dan terbukti efektif meningkatkan hasil belajar dalam pembelajaran PPKn.

\section{Simpulan}

Berdasarkan hasil penelitian dan pembahasan maka dapat disimpulkan beberapa kesimpulan sebagai berikut. (1) Pengaruh model pembelajaran inkuiri dalam pembelajaran PPKn berpengaruh terhadap keterampilan berpikir kritis peserta didik dalam pembelajaran PPKn di SMA Negeri 3 Lumajang. Hal ini ditunjukkan dari nilai $t_{\text {hitung }}>t_{\text {tabel }}$, nilai signifikansi lebih kecil dari 0,01 dan gain score. Pada kelas eksperimen 1 dengan kelas kontrol nilai $t_{\text {hitung }}>t_{\text {tabel }}(3,058>2,000)$ atau nilai $\mathrm{p}$ lebih kecil dari $0,01(\mathrm{p}=0,003<0,01)$. Sementara kelas eksperimen 2 dengan kelas kontrol memiliki nilai $t_{\text {hitung }}>t_{\text {tabel }}(4,245>$ $2,000)$ atau nilai $\mathrm{p}$ lebih kecil dari $0,01 \quad(\mathrm{p}=$ $0,000<0,01$ ). Peserta didik kelas eksperimen 1 dengan model inkuiri memperoleh gain score sebesar 0,72 dalam kategori efektivitas tinggi, peserta didik kelas eksperimen 2 yang juga menggunakan model pembelajaran inkuiri memperoleh skor 0,74 dalam kategori efektivitas tinggi. Sementara pada kelas kontrol yang menggunakan model pembelajaran problem basic learning memperoleh gain score sebesar 0.64 dalam kategori efektivitas sedang. (2) Pengaruh model pembelajaran inkuiri dalam pembelajaran PPKn berpengaruh terhadap hasil belajar peserta didik dalam pembelajaran PPKn di SMA Negeri 3 Lumajang. Hal ini ditunjukkan dari nilai nilai $t_{\text {hitung }}>t_{\text {tabel }}$, nilai signifikansi lebih kecil dari 0,01 dan hasil gain score. Pada kelas eksperimen 1 dengan kelas kontrol nilai $t_{\text {hitung }}>t_{\text {tabel }}(4,498>$ $2,000)$ atau nilai $\mathrm{p}$ lebih kecil dari $0,01(\mathrm{p}=$ $0,000<0,01)$. Sementara kelas eksperimen 2 dengan kelas kontrol memiliki nilai $t_{\text {hitung }}>$ $t_{\text {tabel }}(5,349>2,000)$ atau nilai p lebih kecil dari $0,01(\mathrm{p}=0,000<0,01)$. Peserta didik kelas eksperimen 1 maupun eksperimen 2 dengan model inkuiri memperoleh gain score sebesar 0,31 masing-masing dalam kategori efektivitas sedang. Sementara pada kelas kontrol yang menggunakan model pembelajaran problem basic learning memperoleh gain score sebesar 0,06 dalam kategori efektivitas rendah.

Berdasarkan kesimpulan penelitian ini, ada beberapa saran yang dapat dipaparkan, maka dapat diberikan saran kepada berbagai pihak sebagai berikut. (1) Pengaruh model pembelajaran inkuiri dilakukan secara kelompok, sehingga kemungkinan ada anggota yang kurang aktif, sehingga mengakibatkan keterampilan berpikir kritisnya juga kurang optimal. Oleh karena itu, hendaknya guru dapat membangkitkan peserta didik agar aktif dalam kegiatan pembelajaran dengan cara memberikan bimbingan, motivasi, dan monitoring pada setiap kelompok. (2) Hendaknya guru membiasakan diri untuk menerapkan model pembelajaran inkuiri dengan persiapan yang baik termasuk dari segi peserta didik maupun instrumen yang dibutuhkan, sehingga hasil belajar peserta didik dapat lebih optimal.

\section{Daftar Pustaka}

Hamdayama, J. (2014). Model dan metode pembelajaran kreatif dan berkarakter. Bogor: Ghalia Indonesia.

Ibrahim. (2012). Pengaruh metode inkuri dan pemberian tugas terhadap aktivitas dan pemahaman konsep sains siswa kelas VII SMP Negeri 1 Telu Kabupaten Sumbawa-NTB. Tesis Magister, tidak diterbitkan, Universitas Negeri Yogyakarta. Yogyakarta

Newby, T.J., Stepich, D.A., Lehman, J.D., et al. (2000). Inteructional Technology for Teaching and Learning. New Jersy: Prentice Hall, Inc.

Purwanto. 2014. Evaluasi hasil belajar. Yogyakarta: Pustaka Pelajar.

Puskur. 2010. Pengembangan pendidikan budaya dan karakter bangsa. Jakarta: Puskur Balitbang Kementerian Pendidikan Nasional. 
Samsuri. (September 2013). Paradigma pendidikan kewarganegaraan dalam Kurikulum 2013. In Kuliah Umum Program Studi Pendidikan Pancasila dan Kewarganegaraan. FKIP Universitas Ahmad Dahlan.

Samsuri. (2006). Pembentukan warga negara demokratis dalam pembelajaran pendidikan kewarganegaraan. $P K n$ Progresif, 1(1).
Shoimin, A. (2014). 68 Model pembelajaran inovatif dalam Kurikulum 2013. Yogyakarta: Ar-Ruzz Media.

Silalahi, R. (2011). Kontribusi model pembelajaran kontekstual tipe inkuiri dalam meningkatkan motivasi dan prestasi belajar siswa pada mata pelajaran Pendidika Kewarganegaraan. Jurnal Penelitian Pendidikan, Edisi Khusus(2). 